\title{
Sinema Perdesinde Araştırmacı Gazetecilik: "Spotlight" Filmi Üzerine Sosyolojik Bir İnceleme
}

\author{
İsmail ÖZÇELİK
}

Yüksek Lisans, Selçuk Üniversitesi Sosyal Bilimler Enstitüsü, Radyo Televizyon ve Sinema Anabilim Dalı, Konya, Türkiye, ozcelik0016@gmail.com

\begin{tabular}{|c|c|}
\hline Bilgileri & ÖZ \\
\hline $\begin{array}{l}\text { Makale Geçmişi } \\
\text { Geliş: } 15.08 .2020 \\
\text { Kabul: } 11.11 .2020 \\
\text { Yayın: } 25.12 .2020 \\
\text { Anahtar Kelimeler: } \\
\text { Spotlight, } \\
\text { Araştırmacı Gazetecilik, } \\
\text { Toplumsal, } \\
\text { Sosyolojik. }\end{array}$ & 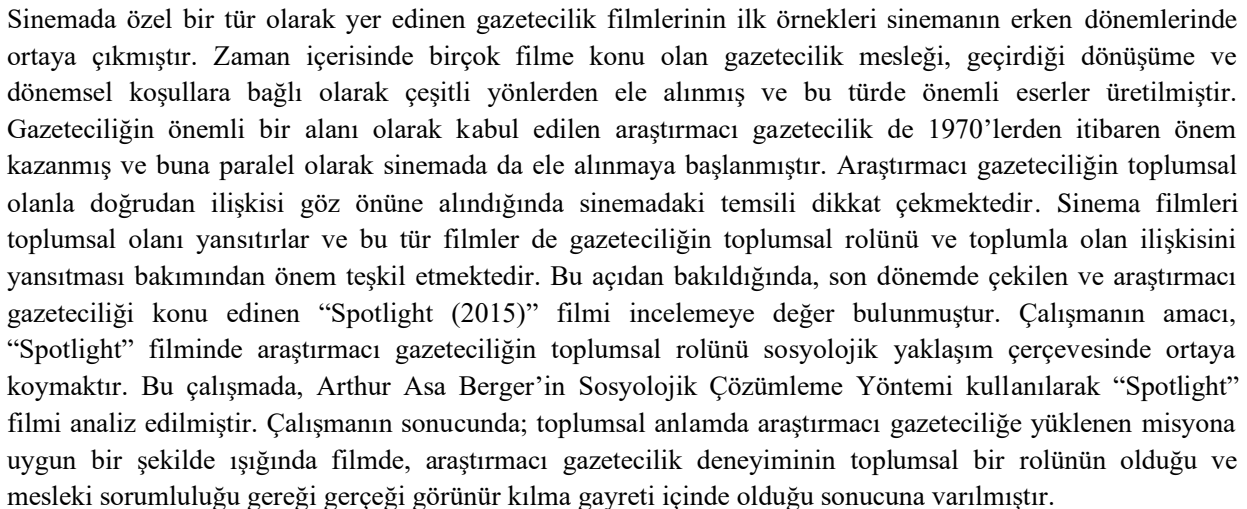 \\
\hline
\end{tabular}

\section{Investigative Journalism On The Cinema Screen: A Sociological Review On The "Spotlight" Movie}

\begin{tabular}{|c|c|}
\hline Article Info & ABSTRACT \\
\hline $\begin{array}{l}\text { Article History } \\
\text { Received: } 15.08 .2020 \\
\text { Accepted: } 11.11 .2020 \\
\text { Published: } 25.12 .2020 \\
\text { Keywords: } \\
\text { Spotlight, } \\
\text { Investigative } \\
\text { Journalism, } \\
\text { Social, } \\
\text { Sociological. }\end{array}$ & $\begin{array}{l}\text { The first examples of journalism films that have gained a place in cinema as a special genre appeared in the } \\
\text { early stages of cinema. The journalism profession, which has been the subject of many films over time, has } \\
\text { been handled from various aspects depending on the transformation it has undergone and periodic conditions, } \\
\text { and such important works have been produced. Investigative journalism, which is accepted as an important } \\
\text { field of journalism, has gained importance since the 1970s and has started to be addressed in cinema in } \\
\text { parallel with this. Considering the direct relationship of investigative journalism with the social, its } \\
\text { representation in cinema is striking. Cinema films reflect the social and such films are important in terms of } \\
\text { reflecting the social role of journalism and its relationship with society. From this point of view, the movie } \\
\text { "Spotlight (2015)", which was shot recently and focused on investigative journalism, was found worth } \\
\text { examining. The aim of the study is to examine the social role of investigative journalism in the movie } \\
\text { "Spotlight" with a sociological approach. In this study, the movie "Spotlight" has been analyzed using the } \\
\text { Sociological Analysis Method of Arthur Asa Berger. As a result of the study; In the light of the mission } \\
\text { attributed to investigative journalism in a social sense, it was concluded that the investigative journalism } \\
\text { experience had a social role in the film and that it strives to make reality visible due to its professional } \\
\text { responsibility. }\end{array}$ \\
\hline
\end{tabular}

Atıf/Citation: Özçelik., İ. (2020). Sinema Perdesinde Araştırmacı Gazetecilik: "Spotlight" Filmi Üzerine Sosyolojik Bir İnceleme, Konya Sanat Dergisi, 3, 32-48.

"This article is licensed under a Creative Commons Attribution-NonCommercial 4.0 International License (CC BY-NC $4.0) "$ 


\section{GİRIŞ}

'Toplumsal yapının aynası' olarak nitelendirilen sinema, bireyin ve toplumun yaşam deneyimini, sosyal varlığını, inançlarını, kültürünü, kısacası toplumun gerçeğini yansıtması bakımından önem kazanmaktadır. Sinemanın ve toplumsal yapının bu ayrılmaz bütünlüğü her filmde kendisini göstermektedir. Güçhan'ın (1993: 52) ifadesine göre sinema, diğer sanatlar ve kitle iletişim araçlarına benzer şekilde toplumsal yapının bir ürünüdür ve buna bağlı olarak dönüşüm yaşamaktadır. Yazara göre, kültürel bir nitelik taşıyan sinema yapıtları kendisini çevreleyen ekonomik, toplumsal, siyasal, tarihsel koşullarla iç içedir ve ayrı olarak düşünülemez. $\mathrm{Bu}$ bağlamda sinema filmleri yansıttıkları toplumsal gerçeklik çerçevesinde bizlere sosyolojik bir inceleme alanı sunmaktadır.

Lale Kabadayı'ya (2018: 54) göre, sinema filmlerinin toplumsal olanı yansıttığı görüşü sinema çalışmalarını en çok etkileyen düşüncelerdendir. Her sinema filmi, üretildiği veya içeriğinde ele aldığ 1 toplumun kültürel kodlarını barındırmaktadır. Bu nedenle filmlere doğru yaklaşabilmek için yansıttıkları kültürü tanımak, bilmek gerekmektedir. Özden'e (2004: 154) göre sosyolojik yaklaşım, filmlerin üretildiği ya da içeriğinde ele alındığı dönemin sosyal koşulları çerçevesinde incelenmesini ifade eder. Bu bağlamda, sosyal değerlerin filmlerde nasıl ele alındığı, ifade edildiği, filmlerin sosyal değerler üzerinde nasıl etkiler gösterdiği ve toplumsal düzeyde nasıl dönüşümlere neden olduğu gibi konular inceleme alanında yer almaktadır. "Filmlerle Sosyoloji” isimli kitaba yazdığı önsözde Slavoj Zizek, filmlerin yalnızca bir film, bir kaçış ya da eğlence aracı olmadı̆̆ını, toplumsal gerçekliği yansıtan ya da toplumun kendini yeniden üretmesini sağlayan bir alan veya araç olduğunu ifade etmektedir (Diken ve Laustsen, 2011: 15).

Arık ve Akgün'ün (2019: 197) ifadesine göre, sinemanın geniş kitlelere kendi söylemini iletebilmesi onu toplumsal temsiller açısından önemli kılmaktadır. Dolayısıyla, toplumsal bir nitelik taşıyan gazetecilik mesleğinin sinemadaki temsili de önem taşımaktadır. Gazetecilik temalı filmlerin ilk örnekleri sinemanın erken dönemlerinde ortaya çıkmıştır. Zaman içerisinde birçok filme konu olan gazetecilik mesleği çeşitli yönlerden ele alınmış ve bu alanda önemli eserler üretilmiştir. Gazeteciliğin önemli bir alanı olarak görülen araştırmacı gazetecilik de çeşitli filmlere konu olmuştur. Araştırmacı gazeteciliğin sinemada özel olarak ele alınmaya başlanması 1970'li yıllara dayanmaktadır. Bu yıllarda yankı uyandıran bazı çalışmalar neticesinde araştırmacı gazetecilik faaliyetleri yaygınlaşmaya başlamış ve bu durum sinema yapımcılarının da dikkatini çekmiştir. Bu bakımdan, The Washington Post'un araştırmacı gazetecileri tarafından 1972-1974 yılları arasında ortaya çıkarılan Watergate Skandalı bir kilometre taşı olmuştur. Araştırmacı gazetecilik açısından bir dönüm noktası olarak kabul edilen bu olay 1976 yılında çekilen Başkanın Bütün Adamları (All the President's Men) adlı filmde ele alınmıştır. Bu film, uzun yıllar boyunca araştırmacı gazetecilik denildiğinde akla gelen ilk film olmuştur. Sayıca çok fazla olmasa da daha sonraki yıllarda araştırmacı gazeteciliği ele alan önemli filmler çekilmiştir. The Killing Fields (1984), The Pelican Brief (1993), Veronica Guerin (2003) ve State of Play (2009) bu bağlamda öne çıkan filmlerdir.

Bu tür filmlerden birisi de gerçek bir hikâye üzerinden şekillenen 2015 yapımı "Spotlight" filmidir. Araştırmacı gazeteciliğin toplumsal rolünü yansıtması bakımından önemli görülen filmde ana tema araştırmacı gazetecilik sürecidir. Boston Globe gazetesine bağlı Spotlight ekibinin 2002 yılında "Kilise Rahiplerinin Çocuk İstismarı" konusu ile ilgili yaptıkları çalışmadan yola çıkılarak çekilen filmde, araştırmacı gazeteciliğin toplumsal rolünün, mesleki misyonu ve sorumlulukları bağlamında nasıl yansıtıldığı sorusu filmin incelenmesi bakımından 
önem kazanmaktadır. Çalışmanın amacı, Spotlight (2015) filminde araştırmacı gazeteciliğin toplumsal rolünü sosyolojik yaklaşım temelinde ortaya koymaktır. Filmde araştırmacı gazeteciliğin toplumsal sorumluluğu, güç odakları ile ilişkisi, suskunluk sarmalı sürecinde oynadığ1 rol, gündem oluşturmadaki etkisi ve toplumsal alanda yarattığı değişim gibi unsurlar yer almakta ve bu da filmi sosyolojik açıdan ele almamıza olanak sağlamaktadır. Filmde, araştırmacı gazetecilik mesleği ve toplumsal boyutlarının kapsamlı bir şekilde ele alınması, çalışmanın faydalı sonuçlara ulaşmasına destekleyecektir.

$\mathrm{Bu}$ çalışma, Arthur Asa Berger'in medya çözümleme ve yorumlama teknikleri üzerine oluşturduğu metodunda belirtilen Sosyolojik (Toplumbilimsel) Çözümleme Yöntemi kullanılarak gerçekleştirilmiştir. Toplumsal ve sosyal olguları açıklamak için kullanılan sosyolojik yöntem, aynı zamanda medya metinlerini incelemek ve yorumlamak için de kullanılmaktadır. Dolayısıyla toplumsal ve sosyal bir nitelik barındıran araştırmacı gazeteciliğin sinemadaki temsilini ele almamız açısından kolaylık sağlamaktadır. Çalışmanın ilk bölümünde, literatürden elde edilen veriler 1şı̆̆ında araştırmacı gazetecilik terimine ve toplumsal rolüne ilişkin kavramsal çerçeve çizilmiştir. İkinci bölümde, araştırmacı gazeteciliğin sinema ile olan ilişkisi ele alınmıştır. Son bölümde ise "Spotlight" filmi üzerinden araştırmacı gazeteciliğin toplumsal rolüne ilişkin bir inceleme yapılmıştır. Çalışmanın sonucunda; toplumsal anlamda araştırmacı gazeteciliğe yüklenen misyona uygun bir şekilde 1şı̆̆ında filmde, araştırmacı gazetecilik deneyiminin toplumsal bir rolünün olduğu ve mesleki sorumluluğu gereği gerçeği görünür k1lma gayreti içinde olduğu sonucuna varılmıştır.

\section{Araștırmacı Gazetecilik Nedir?}

Genel bir tanımlama ile gazetecilik, bireyin ve toplumun sorunlarına çözüm sağlamada yardımc1 olacak bilgilerin iletilmesidir. Bu iletiler günlük dilde "haber" olarak adlandırılmakta ve bu işi yapan kişilere de gazeteci denilmektedir (Tokgöz, 2013: 132-133). Gazetecilik, bireylerin herhangi bir konuda kendi başlarına elde edemeyecekleri bilgileri toplayıp haber yapma işidir. Araştırmacı gazetecilik ise günlük rutin içinde çoğu gazetecinin yapamadığı veya yapamayacağı, derinlemesine araştırma gerektiren ve bunun için de yeterli zaman, entelektüel birikim ve mücadele azmi isteyen bir iştir.

Günümüzde kitle iletişim araçlarının artmasıyla birlikte sürekli hale gelen iletişim, yoğun bir enformasyon dağılımına neden olmaktadır. Ancak bu yoğun enformasyon dağılımının yarattı̆g kirlilik, yaşamın her alanında ihtiyaç duyulan enformasyonun doğruluğu ve gerçekliği kaygısını öne çıkarmış ve gerçek enformasyona ulaşma sürecinde araştırmacı gazeteciliğin ayrıcalıklı bir konuma yerleşmesine neden olmuştur (Armağan, 2012: 77). Dolayısıyla araştırmacı gazetecilik günümüz basınında doğru ve gerçek bilgiye ulaşmanın en önemli ve özverili yollarından biri olarak görülmektedir.

Araştırmacı gazetecilik geleneksel gazetecilikten farklı olarak, açığa çıkmamış veya güç odakları tarafından üstü örtülmüş ve kamu yararı için bilinmesi önem arz eden olay ve olguların sistemli bir soruşturma ile belgelenerek ortaya konulmasını amaçlayan bir gazetecilik türü olmuştur. Araştırmacı gazetecilik genellikle gizli kalmış kamusal meseleler ile ilgilenmektedir ve bu nedenle hem gizli hem de açık kaynakların ve belgelerin kullanılmasını gerektirmektedir (Hunter ve Hanson, 2011:8).

Araştırmacı gazetecilik, kurumlardaki yolsuzluklar, usulsüz eylemler, kamu fonlarının yanlış yönetimi ve toplumun ilkelerini ihlal eden uygulamalar gibi kamuoyunun dikkatini çekmeyen olay veya olguların ortaya çıkarılmasını amaçlar. Bu yanlışlıklar hükümetler, siyasi partiler, kurumlar, kulüpler, yardım kuruluşları, dini kurumlar veya kitle iletişim araçlarıyla ilgili olabilir. Bu konular ile 
ilgili yapılan araştırmaların çoğu medyada bir skandal olarak yansıyabilir (Ekhareafo vd., 2016: 27). Toplumsal sorumluluk ve meslek etiği bağlamında bu tür olay ve olguların ortaya çıkarılması araştırmacı gazetecilik uygulamalarını gerektirmektedir.

Araştırmacı gazeteciliğin çoğu tanımı, toplumsal sonuçlarından ziyade kendine has bilgi toplama özelliklerini vurgulamaktadır (Protess vd., 1991: 5). Örneğin, Paul N. Williams (1978: 12) araştırmacı gazeteciliği entelektüel bir süreç olarak tanımlamakta ve araştırmacı gazeteciliğin fikirleri ve gerçekleri sistemli bir şekilde toplayıp sınıflandırma, seçenekleri doğru analiz etme ve duygudan ziyade mantığa uygun kararlar verme işi olduğunu ifade etmektedir.

Gazetecilik genel anlamda araştırmaya dayalı bir meslek olmasına karşın geleneksel gazetecilik ile araştırmacı gazeteciliği birbirinden ayıran birçok fark bulunmaktadır. Geleneksel gazetecilikte haberlerin hazırlanmasında kullanılan materyaller büyük ölçüde başka kaynaklar tarafından elde edilir. Yani halihazırda olan bilgiler derin bir araştırma gerektirmeden belli kaynaklardan elde edilir ve haberin yaratılmasında kullanılır. Geleneksel gazetecilik daha çok olay merkezli ve tepkiseldir. Araştırmacı gazetecilikte ise konu ile ilgili derin bir araştırma yapılır ve gazeteci genellikle bilgileri kendi araştırmasıyla elde eder (Hunter ve Hanson, 2011: 8).

Elbette hem geleneksel gazeteci hem de araştırmacı gazeteci haber yaparken araştırmacıdır ancak iki gazetecilik türü arasında beceriler, çalışma tarzı, araştırma süreci ve hedefler açısından bazı farklılıklar vardır (Hunter ve Hanson, 2011: 8). Aslında araştırma sürecinin günlük gazeteciliğin bir parçası olduğu varsayılmaktadır. Bütün gazeteciler haber arayışından kaynak seçimlerine kadar gerçeğin en doğru halini bulmak için olayları ideal bir şekilde araştırmak isterler. Ancak günlük gazeteciliğin ayırt edici özelliği onun gerçekte reaktif olmasıdır. Çoğu gazeteci, günlük rutin içinde yeni haberlerin detaylarını ortaya çıkarmak için gerekli olan araştırma zamanından yoksundur. Sonuç olarak araştırmacı gazetecilik geleneksel gazetecilikten farklıdır ve zaman alan araştırma süreçleri ile bunun yarattığı potansiyel yüksek etkili sonuçlar içeren bir uzmanlık alanı olarak görülmektedir (Protess vd., 1991: 5).

Hunter ve Hanson (2011: 9), geleneksel gazetecilik ile araştırmacı gazeteciliği araştırma süreci açısından karşılaştırmaktadır. Buna göre; geleneksel gazetecilikte rutin olarak haberler için bilgi toplanır ve hızlı bir süreç işler. Haber gerekli minimum bilgiyi içerebilir ve çok kısa olabilir. Haberin içeriğindeki bilgiler kaynağın beyanlarına dayanabilir. Araştırmacı gazetecilikte ise araştırma süreci uzun sürebilir ve tutarlılık ile bütünlük sağlanana kadar bilgiler yayınlanmaz. Araştırma, haber yayınlandıktan sonra bile devam edebilir. Haber içeriği maksimum bilgileri içerebilir ve yeterince uzun olabilir. Haberin içeriğindeki bilgiler somut belgelerle desteklenir.

Geleneksel gazetecilikte haberler topluma iletilirken nesnel bir imaj oluşturulmaya çalışılır. Araştırmacı gazetecilikte ise nesnel bilgiler ile gerçeği yansıtmanın yanında, öznel bir amaçla toplumsal dinamiklerde değişim yaratılmaya çalış1ır (Hunter ve Hanson, 2011: 8). Bu bilgiler ışığında değerlendirildiğinde araştırmacı gazetecilik, tarihsel süreci içerisinde reformist bir özellik kazanmış ve toplumsal anlamda sorumluluk üstlenmiştir. Araştırmacı gazeteciliğin amacı sadece topluma bilgi vermek değil, bu bilgiler ile sorunları çözüme kavuşturmak için toplumu harekete geçirmek olarak tanımlanabilir.

Gerçek araştırmacı gazetecilik 21. Yüzyıl'da haber medyasının belirleyici bir özelliği haline gelmiştir. Araştırmacı gazetecilik iyi bir şekilde yapıldığında haberlerin değerlendirildiği standardı belirlemekte, kötü yapıldığında ise haber medyasıyla ilgili suçlamaların yöneltildiği günah keçisi durumuna gelmektedir (Aucoin, 2005: 4). Bu açıdan bakıldığında, araştırmacı gazetecilik geleneksel gazetecilikten daha fazla risk taşıyan, sorumluluğu yüksek ve meşakkatli bir iştir.

Araştırmacı gazeteciliği çevreleyen folklor Amerikan popüler demokrasi idealine çok benzer. 
$\mathrm{Bu}$ gazeteciler kamuoyunun dikkatini çeker ve bilgilendirilmiş bir vatandaş, seçilmiş temsilcilerinden reform talep eder. Politikacılar da sırasıyla düzeltici önlemler alarak yanıt verir. Bu idealize edilmiş perspektif, 1960'ların sonu ve 1970'lerin başında yaygınlaşmaya başlayan araştırmacı gazetecilik örneklerinin yarattığı etkilerin bir sonucudur. Örneğin, bu süre zarfında Vietnam Savaşı ile ilgili yapılan medya açıklamaları neticesinde kamuoyunun savaşa karşı görüşleri değişmiş ve bu da Amerikan dış politikasında değişikliklere neden olmuştur. Aynı şekilde, Watergate olayını anlatan haberler nedeniyle halkın Nixon yönetimine olan güveni kaybolmuş ve yaşanan olaylar neticesinde Nixon istifaya zorlanmıştır (Protess vd., 1991: 3).

Bu bağlamda araştırmacı gazetecilik, geleneksel gazetecilikten yöntem ve hedefleri bakımından farklılık göstermektedir. Aynı zamanda doğru ve gerçek bilgiye ulaşmanın en önemli yollarından biri olarak kabul edilmekte ve haber medyasının önemli bir alanı olarak görülmektedir. Ancak bütün bunların yanında, araştırmacı gazeteciliğin en önemli işlevi kamusal anlamda sorumluluk üstlenerek otoriteleri gözlemek ve soruşturmak olmuştur.

\subsection{Araştırmacı Gazeteciliğin Ahlaki ve Toplumsal Rolü}

Araştırmacı gazeteciliğin en önemli özelliği ahlaki bir vizyona sahip olmasıdır. Bu gazetecilik türü, anlattığı hikayeler ile sadece sıradan yanlışlıkları, suçları veya yolsuzlukları ortaya çıkarmakla kalmaz; sistemsel ölçüde önemli kamusal meselelere çözüm arayarak toplumu ileriye taşımak için çağrıda bulunur (Ettema \& Glasser, 1988: 11-13). Dolayısıyla araştırmacı gazetecilik kavramı yalnız başına gazetecilik işi olarak değerlendirilmemeli ve toplumsal açıdan gördüğü önemli işlev dikkatle incelenmelidir.

Armağan'a (2012: 80) göre araştırmacı gazeteciliğin tek amacı toplumsal yaşamda ortaya çıkan önemli problemleri sistematik olarak inceleyip raporlamak ve işlenen suçları yargıya taşıyı çeşitli yaptırımların gerçekleşmesini sağlamak değildir. Bunların yanında asıl amaç çözüm önerileri sunarak karar mekanizmalarını etkilemek ve sistemsel boyutlarda kalıcı değişimler sağlayarak toplumsal yaşamı ileriye taşımaktır. Ekhareafo ve arkadaşları (2016: 29) araştırmacı gazeteciliğin topluma karşı sorumlu olduğunu söylemekte ve araştırma raporlarının işlevlerini şöyle sıralamaktadırlar; toplumu iyileştirmeye ve ahlaki açıdan bilinçli bir toplum yaratmaya yardımcı olmak, devlet ve kamu kurumlarında hesap verme sorumluluğu getirmek, kamusal ve sosyal kurumlar hakkında bilinçli görüşler yansıtmak, medyaya olan güveni arttırmak.

Hunter ve Hanson'a (2011: 10) göre araştırmacı gazetecilik sadece elde edilen iyi bir haber ürünü değildir aynı zamanda bir hizmettir ve bu hizmet insanların yaşamlarını daha güçlü ve daha iyi bir hale getirebilir. Aucoin'e (2005: 3) göre tarihsel olarak gerçek araştırmacı gazeteciliğin amacı, ahlaki öfkeyi harekete geçirecek olan yasadışı hikayeleri ortaya çıkarıp anlatmak ve kamu yararı açısından önemli olan sistemsel problemlere odaklanmaktır. Bazı önemli muhabirler araştırmacı gazeteciliği önemli kamusal meseleler hakkında daha önceden bilinmeyen, gizli olan veya açı̆̆a çıkarılması gereken bilgileri özgün bir şekilde haber yapan gazetecilik türü olarak tanımlamaktadır.

$\mathrm{Bu}$ görüşler çerçevesinde araştırmacı gazetecilik uygulamaları toplumsal açıdan sorumluluk arz eden ve toplumları ileriye taşıyacak bilinci harekete geçirmeyi amaçlayan, demokratik söylem içerisinde toplumsal ve ahlaki bir vizyon üstlenmiş bir gazetecilik türüdür. Araştırmacı gazetecilik, tarihsel açıdan bu vizyonu yansıtan bir gelenek oluşturmuş ve başta ABD olmak üzere dünyanın her yerinde yapılan araştırmacı gazetecilik uygulamalarıyla bu reformist tavrı sergilemiştir. Demokratik toplumlarda kendine uygulama alanı bulan araştırmacı gazetecilik faaliyetleri bu toplumların iyileşmelerine katkıda bulunmuştur.

Amerikan gazetecilik tarihi araştırmacı gazetecilik geleneği açısından oldukça zengindir. 20. Yüzyıl'ın başında, ABD başkanı T. Roosvelt tarafından "Muckrakers (Pislik Eşeleyiciler)" olarak 
nitelendirilen dönemin araştırmacı gazetecileri bu sıfatı gururla taşıyarak birçok önemli araştırma raporu yayınlamışlardır (Brooks vd., 1985: 388-389). Amerikan araştırmacı gazeteciliği, "Muckrakers" olarak adlandırılan bu araştırmacı gazetecilerin hikayeleriyle farklı bir boyut kazanmıştır. Bu gazeteciler birçok toplumsal sorunu gündeme taşıyarak araştırmacı gazeteciliğin gelişimine önayak olmuşlardır (İrvan, 2018: 76).

$\mathrm{Bu}$ dönemin araştırmacı gazetecilerinden olan Lincoln Steffens, Amerika'daki bazı şehir yönetimlerini inceleyerek politik yolsuzluklarda parmağı olan iş adamları ve politikacıların yozlaşmış uygulamalarını ortaya çıkarmıştır. Aynı dönemde Ida Tarbell, Standard Oil adlı petrol tekelinin yolsuzluklarını yazmıştır. Theodore Dreiser, Upton Sinclair ve Frank Norris ise bazı gıda fabrikaları ve paketleme servislerindeki çalışma hayatının kötü koşullarını ortaya çıkarmıştır (Brooks vd., 1985: 389). 1903 ve 1912 yılları arasında Amerikan dergilerinde 2 binden fazla araştırma raporu yayınlanmış ve bunların etkisiyle bazı kısa süreli sosyal ve siyasi reformların yolu açılmıştır (Aucoin, 2005: 33).

ABD'deki araştırmacı gazetecilik uygulamalarından bazıları dünya çapında yankı uyandırmış ve araştırmacı gazeteciliğin ileride daha etkin bir şekilde yapılmasına katkıda bulunmuştur. $\mathrm{Bu}$ uygulamalardan bazıları da kitaplara ve filmlere konu olarak daha bilinir hale gelmiştir. Özellikle 1960 ve 1970'li yıllarda öne çıkan bazı araştırmacı gazetecilik örnekleri tarihsel süreçte dönüm noktası olmuş ve araştırmacı gazeteciliğin yayılmasına önayak olmuştur.

ABD tarihinde araştırmacı gazetecilik açısından en önemli gelişmelerden birisi Seymour Hersh'in, ABD ordusunun Vietnam'daki My Lai köyünde gerçekleştirdiği katliam ile ilgili 1969' da yaptığı çalışmadır. Vietnam'daki katliamların sivillere yönelik olarak gerçekleştiğini yaptığı haberler ile ortaya koyan Hersh, ABD ordusunun Vietnam'da yaptığı uygulamalar ile ilgili olarak Amerikan halkını bilgilendirmiştir. Hersh'in haberleri neticesinde ortaya çıkan bilgiler ABD'de dikkat çekmiş ve Amerikan halkının Vietnam Savaşı'na yönelik bakışı değişmiştir. Seymour Hersh'in bu çalışmasının araştırmacı gazetecilik açısından önemi, ortaya çıkardığı bilgiler ile iktidarı hesap vermeye zorlaması ve toplumun olaylara bakışını değiştirmeye neden olmasından kaynaklanmaktadır (Öncel, 2012: 62$63)$.

Araştırmac1 gazeteciliğin değişim yaratmak için güçlü bir katalizör görevi üstlenebileceği düşüncesi Watergate olayı sonrası Amerika'da yaygın olarak kabul görmüştür. Bu süreçte halk, suistimal ve yanlış bilgiler içeren olayları ortaya çıkaran mücadeleci gazetecilerin haberleriyle karşı karşıya kalmıştır. Araştırmacı gazeteciliğin bu reformcu imajı Watergate sonrası Amerika'da filmler ve kitaplar ile daha da güçlenmiştir (Protess vd., 1991: 3).

"Watergate Skandalı" olarak nitelendirilen olay Washington Post gazetesinin çalışanları olan araştırmacı gazeteciler Carl Bernstein ve Bob Woodward'ın 1972 yılında gün ışı̆̆ına çıkarmaya başladıkları ve 1974'e kadar süren, ABD başkanı Nixon'1 istifaya götüren politik yolsuzlukların medyadaki yansımalarıdır. Adını ABD'nin başkenti Washington'daki bir otel ve iş merkezinden alan Watergate Skandalı, Richard Nixon'un Cumhuriyetçi Partisi ile bağlantılı olan hırsızların ana muhalefet partisi olan Demokrat Parti'nin bürosuna girip telefonlarını gizlice dinlemek için mikrofon yerleştirmeleri sırasında yakalanmaları sonucu açığa çıkmıştır. Washington Post gazetesi muhabirleri Carl Bernstein ve Bob Woodward, bu olay ile ilgili haberler yaparken gizli kaynaklardan elde ettikleri bilgileri doğrulayarak kullanmışlardır. ABD başkanı Richard Nixon bu gelişmeler sonucunda itibarını ve halkın desteğini kaybetmiş ve hakkında soruşturmalar açılmıştır. Sürecin sonucunda istifa eden Richard Nixon ABD tarihinde istifa eden ilk devlet başkanı olmuştur (Öncel, 2012: 63-64).

Washington Post Gazetesi'nin ve araştırmayı yürüten muhabirler Carl Bernstein ile Bob Woodward'ın Watergate Skandalı çalışması tarihe iyi bir araştırmacı gazetecilik örneği olarak geçmiş ve araştırmacı gazetecilik açısından önemli bir dönüm noktası olmuştur. Watergate Skandalı daha 
sonra birçok kitaba ve filme konu olmasının yanında ABD'de birçok araştırmacı gazetecilik çalışmasının yolunu açmıştır.

Önemli bir araştırmacı gazetecilik örneği ise 2000'li yılların başında Boston Globe Gazetesi'nin araştırma ekibi olan Spotlight'1n, Boston'daki Katolik Kilisesi rahiplerinin çocuklara yönelik gerçekleştirdiği cinsel istismarı ortaya çıkaran haberlerdir. Boston'daki Katolik Kilisesi rahiplerinin yıllarca süren çocuk istismarı kilise yönetimi tarafından gizlenmiş, rahiplere yönelik açılan davalar engellenmiş ve Kardinal Bernard Law'in olaylardan haberi olduğunu gösteren belgeler mühürlenmiştir. Kilise, yıllarca gizlenen istismar olayını ortaya çıkarmaya çalışan gazeteciler, avukatlar veya sivil mağdurlara yönelik susturma çabaları içine girmiştir. Spotlight ekibinin olayı araştırmaya başlamasıyla gerçekler gün yüzüne çıkmış ve yüzden fazla rahibin çeşitli cemaatlerde çocuklara cinsel istismarda bulunduğu ve kilise yönetiminin bunlardan haberdar olmasına karşın olayları gizlemeye çalıştığı ortaya çıkmıştır (Rezendes, 2002).

Yukarıda verilen örnekler 1şığında araştırmacı gazeteciliğin toplumsal yapı ile arasındaki doğrudan ilişkisi vurgulanmıştır. Araştırmacı gazetecilik mesleğinin tarihsel süreç içerisinde kamu yararı gözeten reformist bir misyona sahip olduğu görülmektedir. Araştırmacı gazetecilik, gerçekleri ortaya çıkararak toplumu bilgilendirmek, bilinç oluşturmak ve toplumu harekete geçirmek istemektedir. Bu hedefler doğrultusunda toplumun iyileşmesine ve ilerlemesine katk1 sağlayacağı düşünülmektedir.

\subsection{Demokrasi Anlayışı Çerçevesinde Araştırmacı Gazetecilik}

John O'neill'in ifadesine göre, liberal yaklaşım içerisinde gazetecilik söz konusu olduğunda demokrasi ve özgür basın arasında özel bir ilişki kurulmaktadır. Kuvvetler ayrılığı ilkesine göre birbirinden ayrılan ve demokrasinin vazgeçilmezi olan yasama, yürütme ve yargının yanında dördüncü güç olarak konumlandırılan basın, demokrasinin işleyişi için önemli bir unsur haline gelmiştir. Liberal yaklaşıma göre özgür basın, demokrasilerde bir denetimci veya gözlemci işlevi görür. Otoriteleri, hükümetleri, güç odaklarını vb. sorgular ve kamuoyu oluşturur. Bunun yanında farklı fikir ve bakış açılarını yansıtarak toplumu bilgilendirir ve demokrasinin çok seslilik ilkesine katkı sağlar (Akt. Uzun, 2006: 635). Bu yaklaşım çerçevesinde medya ve basına yüklenen demokrasi işlevi hem demokrasinin işleyişine etkisi hem de kendi kurumları içerisinde işlerliği ölçüsünde değerlendirilmelidir. Ancak yaklaşık yarım asırdır medyaya ve basına yöneltilen en önemli eleştiri demokrasinin işleyişi adına üstlendiği görevleri yerine getirememesidir. Günümüzde ise medya, özgür bir düşünce alanı ve tartışma ortamı yaratmış olması gerekirken kendisi tartışmaların odağı haline gelmiştir. Zamanla medya kurumları güç odakları ve otoritelerin çıkarlarına hizmet etmeye başlamışlardır. Bu durumun sonucunda ise araştırmacı gazeteciliğe olan ihtiyaç artmıştır (Öncel, 2012: 1,20,32).

"Kamu gözcüsü” olarak da nitelendirilen medyanın klasik liberal yaklaşım çerçevesinde en temel demokratik işlevinin devleti gözlemek olduğu varsayılmaktadır. Bu söylem günümüzde özellikle araştırmacı gazeteciler tarafından benimsenmekte ve daha çok devlet otoritesinin kötüye kullanılmasını ortaya çıkarmak şeklinde tanımlanmaktadır. Medyanın "kamu gözcüsü" olarak ifade edilen bu rolü diğer işlevlerinden daha önemli görülmektedir. Bunun nedeni, medyanın hak ve özgürlükleri çerçevesinde bir kamusal sorumluluk üstlenmesi ve kamu adına eleştiri yapmasıdır (Akçalı, 1998: 172).

Öncel'in (2012: 33) ifadesine göre, araştırmacı gazeteci medyada profesyonel gazeteci kimliği ile denetim işlevini yerine getirmeye çalışırken çeşitli zorluklarla karşılaşır. Bunun nedeni ise ülkenin siyasal, ekonomik ve kültürel atmosferi ile araştırmacı gazetecinin çalıştığı kurumun ideolojisi, işleyişi ve ilişkileridir. Medya kurumlarının ekonomik, siyasi vb. güç odakları ile kurdukları ilişkiler sonucunda profesyonel gazetecilik alanı ayrışmıştır. Bu ayrışma sonucunda profesyonel gazetecilik, 
kamu yararı gözeten, mevcut otoritelerin ve güç odaklarının uygulamalarını takip eden bir sistem olarak ortaya çıkmıştır. Bu misyon özellikle araştırmacı gazetecilere yüklenmektedir. Medya kurumlarının ekonomik sürekliliği sağlamak adına oluşturdukları kâr amaçlı sistemleri profesyonel gazeteciliği zedelemektedir. Klasik liberal yaklaşımın ileri sürdüğü medya söylemi ile mevcut medya sistemi tezat oluşturmaktadır. Bu bağlamda mevcut sistemin koşulları içerisinde medyanın demokratik rolünü gerçekleştirmesi ve özelde de araştırmacı gazetecilerin görevlerini yapmaları zorlaşmaktadır.

Medya kurumlarının kar odaklı ticari yapıları, araştıran ve sorgulayan gazetecilerden daha çok medya sahiplerinin ideolojileri, çıkarları ve ilişkilerine uyum sağlayan gazetecilerin yer bulmasına ve itibar görmesine neden olmaktadır. Buna bağlı olarak da idealist gazetecilerin sistemin dışına itilmesi gündeme gelmektedir. Medyada çıkar ilişkileri çerçevesinde haber üretim sürecine girilmesi medya yöneticileri adına olumlu sonuçlar doğururken bu sürece dahil olmayan gazetecilerin ise dışlanmalarına neden olmaktadır. Araştırmacı gazetecilik de bu süreçten en çok etkilenen alanlardan birisidir. Medyanın ve gazeteciliğin demokrasi adına üstlendiği gözleyici ve denetleyici rol artık kabul görmezken medya sahiplerinin çıkarlarına hizmet etmek daha makul bir yol olarak görülmektedir (Öncel, 2012: 50-51).

Medyanın ideolojik ve ticari yapısından kaynaklanan sorunlar araştırmacı gazeteciliğin gelişimi açısından olumsuz sonuçlar doğurmaktadır. Ancak araştırmacı gazeteciler medya sistemi içinde yaşanan tüm olumsuzluklara rağmen gerçeği yansitan haberler yapmaya ve toplumu bilgilendirmeye devam etmektedirler. Araştırmacı gazetecilik, haber medyası içerisinde hak ettiği konuma ulaşamamış olsa da gerçek ve doğru bilgiye ulaşmada ona duyulan ihtiyaç her dönemde güncelliğini korumaktadır.

\section{Sinemada Araştırmacı Gazetecilik}

Film yapımcılarının gazetecilik mesleğine karşı duydukları ilgi sinemanın ilk zamanlarına kadar uzanmaktadır. It Happened One Night (1934), His Girl Friday (1940) gibi Screwball ${ }^{1}$ klasiklerinden Shattered Glass (2003) ve A Mighty Heart (2007) gibi çağdaş dramlara kadar, Orson Welles (Citizen Kane, 1940), Billy Wilder (Ace in the Hole, 1951) ve Alexander MacKendrick (Sweet Smell of Success, 1957) gibi yönetmenlerin başyapıtlarıyla gazetecilik mesleği, birçok yetenekli yönetmene en iyi işlerini yapmaları için ilham vermiştir (McNair, 2011: 366).

Gazetecilik filmleri olarak adlandırılan bu filmler sinemada özel bir tür olarak yer edinmiştir. Buradaki tür ifadesi özel bir alanı sınıflandırma açısından kullanılmaktadır. Aslında gazetecilik filmleri Western, müzikal veya kara film gibi tam bir tür oluşturmamaktadır. Bu filmler gazeteciliği veya gazeteci kimliğini çeşitli biçimlerde ele alan geniş bir filmografi oluştursa da bir film türünü sağlayacak ortak özellikleri barındırmamaktadır. McNair'in (2011: 366) ifadesine göre, aslında tüm meslekler arasında yalnızca polisler ve dedektifler gazeteciliğe benzer şekilde film yapımcılarının görüş alanında merkezi bir yer tutmuştur. Ehrlich'in (2004: 12-13) aktarımına göre bir gazetecilik filmografisi 2.000' den fazla filmi kapsamaktadır. Ancak bu filmlerin çoğunda gazeteciler çevresel roller oynamaktadır. Gazetecilerin başrol oyuncusu olduğu veya gazeteciliğin olay örgüsünün anahtarı olduğu filmler azdır. Bu filmlerden bazıları Amerikan filmlerinin en iyileri arasında sayılır.

Gazetecilik filmleri arasında dikkat çeken filmlerden bazıları da araştırmacı gazeteciliğe odaklananlardır. Araştırmacı gazeteciliği konu edinen bu filmler gazetecilik mesleğine ilişkin önemli bir kaynak oluşturmaktadır. Araştırmacı gazeteciliğin sinema perdesinde yer alması sürecinde Alan Pakula'nın All The President's Men (1976) filmi önemli bir dönüm noktasıdır. Bu filmde The Washington Post Gazetesi'nin ünlü muhabirleri Carl Bernstein ve Bob Woodward'ın Watergate Skandalı'nı ortaya çıkardıkları araştırma sürecine odaklanılmaktadır. Aynı zamanda araştırmacı

\footnotetext{
${ }^{1}$ Sinemada sesin kullanılmaya başlanmasıyla birlikte Hollywood'da ortaya çıkan ve 1930'lı yıllar boyunca etkin olan komedi filmi türüdür.
} 
gazeteciliğin gelişimi açısından da önemli bir dönüm noktası olarak görülen Watergate Skandalı çalışması Alan Pakula'nın filmi ile birlikte araştırmacı gazeteciliğin dikkat çekmesini sağlamıştır.

All The President's Men "gazeteciliğin ne kadar önemli ve etkili olduğu" hakkında bir film olarak öne çıkmakta ve araştırmacı gazeteciliğe dair önemli bir çerçeve sunmaktadır. Araştırmacı gazeteciliğin medya yöneticileri üzerindeki ekonomik baskılar nedeniyle risk altında olduğunun anlaşıldığı bir çağda Pakula'nın filmi, liberal demokratik toplumların kolektif vicdanını rahatsız etmeye ve vatandaşlarına gazeteciliğin ne işe yaradığını hatırlatmaya olanak sağlamıştır (McNair, 2011: 366).

Daha sonraki yıllarda araştırmacı gazeteciliği konu edinen bazı filmler çekilmiş olsa da araştırmacı gazetecilerin başrol oynadığı veya olay örgüsünde araştırmacı gazeteciliğin etkin olduğu filmlerin sayısı fazla değildir. Bu filmlerden öne çıkan bazıları: The Killing Fields (1984), The Pelican Brief (1993), Veronica Guerin (2003) ve State of Play (2009) filmleridir.

1984 yapımı The Killing Fields filminde, The New York Times gazetesi muhabiri Sydney Schanberg'in 1970'lerdeki Kamboçya iç savaşını takip ettiği sürece odaklanılmaktadır. 1993 yapımı The Pelican Brief filminde de bir araştırmacı gazetenin bir hukuk öğrencisi ile birlikte iki yargıcın şüpheli ölümünü açıklığa kavuşturma çabası anlatılmaktadır. 2003 yapımı Veronica Guerin filmi ise yaptığı haberler nedeniyle 1996 yılında uyuşturucu mafyası tarafından öldürülen araştırmacı gazeteci Veronica Guerin'in hayatına odaklanmaktadır. 2009 tarihli State of Play filmi, bir Amerikan kongre üyesinin asistanı ve metresinin şüpheli ölümü üzerine araştırmacı gazeteci Cal McCaffrey'in olayı araştırdığı sürece odaklanmaktadır.

Gazetecilik filmleri üzerine bazı akademik çalışmalar yapılmış olsa da genel anlamda yeterli bir literatür oluşmamıştır. Özellikle sinemada araştırmacı gazeteciliğin temsiline ilişkin neredeyse yok denecek kadar az çalışma vardır. Günümüzde hala birçok yönetmenin ilgi alanlarından olan basın ve gazeteciliğin beyaz perdedeki konumunu araştırmak hem sinema hem de gazetecilik açısından önemli bir uygulamadır.

\section{3. “Spotlight (2015)” Filminin Sosyolojik İncelemesi}

Yönetmenliğini Tom McCharthy'nin yaptığı "Spotlight (2015)" filmi, Boston Globe gazetesinin araştırma ekibi olan Spotlight' 1 2002'de haber yaptığ 1 gerçek bir hikâyeden yola çıkılarak çekilmiştir. Filmde, Boston'daki Katolik Kilisesi rahiplerinin cemaatlerdeki çocuklara yönelik cinsel istismarını açığa çıkaran Spotlight ekibinin bu olayı araştırdığı sürece odaklanılmaktadır. Spotlight ekibine 2003 yılında Pulitzer Kamu Hizmeti Ödülü'nü kazandıran bu çalışmanın araştırma sürecini anlatan filmdeki olaylar ve karakterler gerçeklerden yararlanılarak tasarlanmıştır.

Boston Globe gazetesine yeni gelen baş editör M. Baron ilk iş olarak gazetenin diğer editörleri ile bir toplantı düzenler. Bu toplantıda Baron, Eileen McNamara tarafindan Globe'un bir köşe yazısında ele alınan Katolik Kilisesi rahiplerinin cinsel istismarı konusunu gündeme getirir ve bu olayın üzerine gidilmesi gerektiğini belirtir. Baron'un isteği üzerine bu görev Spotlight ekibine verilir. Spotlight ekibi araştırmaya başlar ancak Kilise tehdidi nedeniyle süreci gizlilik içerisinde yürütür. Kilisenin alacağı tutum karşısında herkes kaygılıdır ancak Spotlight ekibi olayın üzerine gitmekten çekinmez.

Spotlight ekibinin editörü Walter Robinson ve araştırmacı gazeteciler Sacha Pfeiffer, Michael Rezendes ile Matt Caroll işe eski gazete haberlerini tarayarak başlarlar. Daha sonra mağdurlarla, onların avukatlarıyla ve mağdurlar için açılan derneklerin yöneticileriyle görüşürler. Spotlight ekibi araştırmayı ilerlettikçe yeni vakalarla karşılaşır ve birçok şüpheli rahibin ismine ulaşır. Ekip, olaylara kaç rahibin bulaştığını öğrenmek için kilise kayıt defterlerini gözden geçirir ve suça karışan rahiplerin 
durumuna benzer şekilde, birçok rahibin çeşitli sebeplerle görev yerlerinin değiştirildiği sonucuna varır. Suçlu rahiplerin bu tür yöntemlerle korunduğunu ve olayların açığa çıkmaması için kilise yönetiminin yaşananları örtbas ettiğini ortaya çıkarırlar. Araştırma ilerledikçe Spotlight ekibi 87 rahibin ismine ulaşır. Ancak ekip bununla yetinmez ve olayın derinine inmek, kilise yönetiminin olaylardan haberdar olduğunu kanıtlamak ister. Bunun üzerine ekip, mağdurların avukatı Mitchell Garabedian'ın desteğiyle bazı belgelere ulaşır. Ayrıca ekibin editörü Walter Robinson elde ettikleri isim listesini eski arkadaşı olan ve daha önce kilise davalarına bakan Jim Sullivan'a onaylatır. Yaklaşık bir sene süren araştırma sonucunda Spotlight ekibinin çalışması Globe'da yayınlanır. Medyaya skandal olarak yansıyan bu haber büyük bir yankı uyandırır. Son sahnede ise başka birçok mağdurun Spotlight ekibinin telefonlarını aradığg görülür.

\subsection{Topluma Dışarıdan Bakmak}

Basında nelerin haber olup nelerin olmayacağına karar veren ve seçim yapan kişilere "eşik bekçisi" denilmektedir. Boston Globe gazetesine yeni gelen baş editör M. Baron bir eşik bekçisi olarak neyin haber yapılıp yapılmayacağına karar vermektedir. Filmde M. Baron'un Globe'a gelir gelmez yaptığ 1 ilk iş editörleri ile bir toplantı düzenleyerek Eileen McNamara'nın köşe yazısında ele aldığı Katolik Kilisesi rahibi J. Geoghan'ın cinsel istismar olayını gündeme taşımak olmuştur. Baron bu olayın gazete için önemli olduğunu ve büyük bir haber olacağını söylediğinde herkes şaşırır ve bazıları kiliseye karşı tavır almanın pek akıllıca olmayacağını söyler. Buna rağmen Baron bunun önemli olduğunu ifade eder ve olayın üzerine gidilmesini ister. $\mathrm{Bu}$ araştırmayı da Spotlight ekibinin yapmasını ister. Ancak filmin ilerleyen kısımlarında kilise rahiplerinin cinsel istismarı konusuyla ilgili birçok kişinin daha önceden Globe'a ve Spotlight ekibinin editörü Robby'e başvurduğu ve olayla ilgili belge gönderdikleri görülür. Oysa gazete, olayla ilgili birkaç makale hazırlamak dışında fazla bir şey yapmamış ve olayın üstüne gitmemiştir. Aynı şekilde Spotlight ekibinin editörü Robby'de bu konuyla ilgilenmemiştir. Fakat olayın yıllar sonra tekrar gündeme gelmesi kafalarda bazı soru işaretleri oluşturmuştur. Gazetenin editörleri zamanında bu olaya dikkat çekmezken yeni gelen editör M. Baron bu olayı neden gündeme taşımışıır? Film bu soruya ilerleyen sahnelerde şu şekilde cevap vermektedir; M. Baron bir Yahudi'dir ve Boston'lu değildir. Yani Baron bir yabancıdır ve olaya da yabancı bir gözle bakmaktadır.

Boston'da halkın çoğunluğu Katolik'tir ve Katolik Kilisesinin nüfuz alanı geniştir. İnsanlar kiliseye fazlasıyla itibar etmektedirler. Ancak asıl önemli olan kilisenin bu olayları örtbas etmek için gösterdiği çabadır. Güçlü bir kurum olarak kilise, olaydan haberi olan kişileri yıllar boyunca susturmaya çalışmış ve olayı gizli tutmuştur. Bu suskunluk sarmalı sürecinde olayın mağdurları seslerini duyurmaya çalışsalar da bir sonuç elde edememişlerdir. Çünkü gazeteler de dahil büyük bir kesim kiliseye itibar etmekte ve olayı açığa çıkarmaya çalışan azınlığı ise kilise zor yoluyla susturmaktadır. $\mathrm{Bu}$ nedenle mağdurlar ve mağdurların avukatları toplumun dikkatini çekmeyi başaramamışlardır.

Burada asıl dikkat edilmesi gereken, devletin ideolojik aygitlarından biri olarak dini kurumların toplumun üzerinde böylesine güç sahibi olmalarıdır. Bu kurumlara atfedilen kutsallığın aynı zamanda bu kurumları dokunulmaz hale getirdiği görülmektedir. Filmde de bu noktaya dikkat çekilir; çoğunluk, cinsel istismar suçuna bulaşan kilise rahiplerinin sadece birkaç istisnadan ibaret olduğu düşüncesindedir. Olaya karışanların sayısı artmaya başladığında ise aynı çoğunluk buna inanmak istemez. Aynı şekilde Globe'un editörleri de daha önce bu konuya dikkat etmemiş ve Baron gelene kadar bu olayın gerçekliğini göz ardı etmişlerdir.

Filmde bu durumu, ekibin muhabiri M. Rezendes ile M. Garabedian'in bir restoranda görüştükleri sahnede Garabedian'ın söyledikleri neticesinde anlarız: 
M. Garabedian: ...Yeni editörünüz Yahudi değil mi?

M. Rezendes: Evet, öyle.

M. Garabedian: Işse baksana adam geliyor birden gözler kiliseye dönüyor. Neden biliyor musun?

M. Rezendes: Hayır.

M. Garabedian: Çünkü işe yabancı gözle bakılması gerekiyor. Tıpkı benimki gibi. Ermeni'yim ben. Boston'da kaç tane Ermeni tanıyorsun?

M. Rezendes: Globe'da çalışan Steve Kurkjin.

M. Garabedian: Ikki etti. Kendini ödüllendirmen falan gerekir....

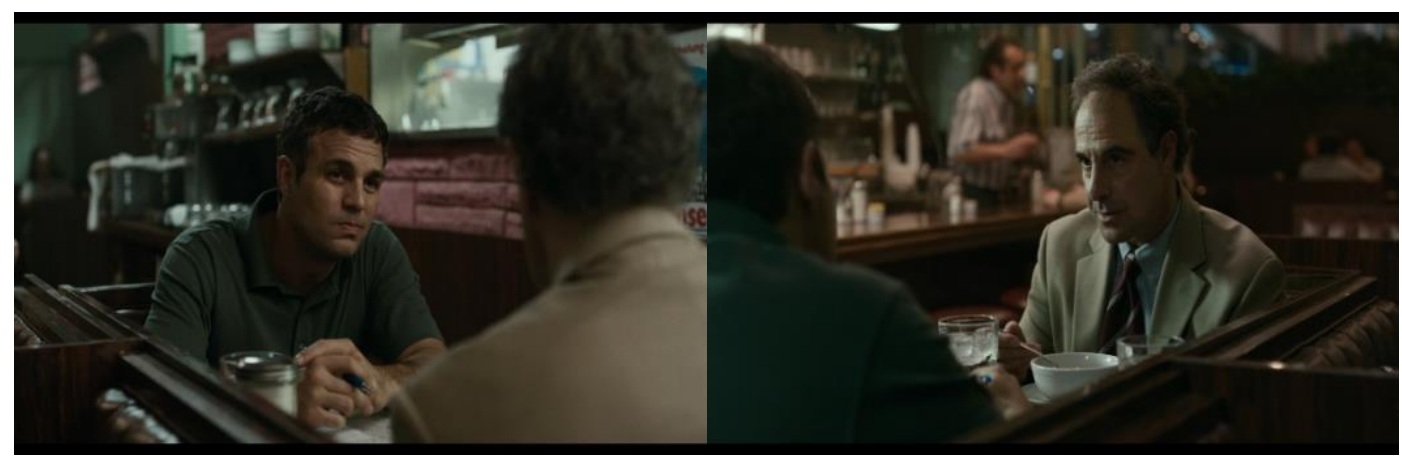

Görsel 1. M. Rezendes ile Avukat M. Garabedian bir restoranda görüşmektedirler.

M. Baron gibi M. Garabedian da bir yabancıdır ve mağdurların avukatlığını yapmaktadır. Garabedian da konuyla ilgili basının dikkatini çekmeye çalışmış ancak başarılı olamamıştır. Oysa bir yabancı olarak Baron, Globe'un editörü ve gazetenin eşik bekçisidir. Mesleği gereği olaya dikkatleri çekebilmek için Garabedian'dan daha avantajlıdır. Kiliseyi karşılarına almanın zor olacağını bilse de Baron bu konunun üzerinde durur. Spotlight ekibi araştırmasını derinleştirdikçe ortaya çıkan problemin sistemsel olduğunu gören Baron, bu durumun daha da önemli olduğunu ve kilisedeki yozlaşmanın tüm detayları ile ortaya konulması gerektiğini söyler. Kilisede sistemsel bir yozlaşmanın olabileceğini ve bunun üzerine gidilmesi gerektiğini düşünen kişinin bir yabancı olması aynı zamanda medyanın ve toplumun dini bir kuruma olan zaafını göstermektedir.

\subsection{Suskunluk Sarmalı Kıskacında Araştırmacı Gazetecilik}

Suskunluk sarmalı kuramına göre bireyin savunduğu görüş toplumun kabullerine uygun değilse bu birey toplumdan dışlanma korkusu nedeniyle görüşlerini açığa çıkarmak istemez. Ancak, bireyin görüşleri toplumun kabullerine uygunsa birey görüşlerini yüksek sesle söylemekten çekinmez. Filmde Katolik Kilisesinin mağdurlara ve avukatlarına karşı uyguladığı susturma çabaları ve 30 yıl boyunca gizlenen olaylar toplumun girdiği suskunluk sarmalını gözler önüne sermektedir. Olaylardan haberdar olanlar kilisenin gücünden korktukları için ya da kiliseye karşı tavır almanın onlar için akıllıca olmayacağını düşündükleri için konuşmaktan çekinmektedirler. Ancak Spotlight ekibi, araştırma sürecinde veya skandalı ortaya çıkardıktan sonra birçok insanın konuşmasına yardımcı olmuştur. Bir araştırmacı gazetecilik ekibi olarak Spotlight ekibi toplumun sesi olarak suskunluk sarmalını kırmayı başarmıştır.

Cinsel istismar olaylarında Boston'lu bireyleri suskunluğa iten en önemli etken kilisenin ve din adamlarının itibarının ve nüfuzunun güçlü olmasıdır. Olayların peşine düşenleri engellemeye çalışan kilise yönetiminin bu gücü aynı zamanda yargı ve emniyet gibi diğer kurumlarla olan ilişkisine de bağlıdır. Filmin geçmişe dönük olan daha ilk sekansında polis merkezindeki memurların ve savcının 
rahip Geoghan'ı serbest bırakmak için ve olayı gizli tutmak için işbirliği içinde olduğu görülmektedir. Dolayısıyla bireyleri susturmaya yönelik gerçekleşen çabada bir kurum olarak kilisenin tek başına olmadığı ve toplumun en önemli kurumlarıyla işbirliği yürüttüğü görülmektedir. Bu durumun neticesinde de yozlaşmanın dini kurumlar ile sınırlı olmadığını ve gerçekleri ortaya çıkarmaya teşebbüs edenlere karşı sistemsel bir zorlama uygulandığını anlarız. ABD’nin demokrasi anlayışına ters düşen bu gibi durumlarda özellikle basının ifade özgürlüğü ve toplumsal sorumluluğu önem kazanmaktadir.

Yaşananlar karşısında girilen suskunluk sarmalının varlığı filmin genelinde görülmektedir. Önce mağdurlar, aileleri ve avukatları bu suskunluk sürecine zorlanmış ve daha sonra ise basın da dahil bütün toplum bu sürece itilmiştir. Seslerini duyurmak için mücadele eden mağdurlar, avukatlar ya da mağdur dernekleri ise dikkat çekememiştir. Toplumdaki bu suskunluğun kırılmasını sağlayan ise basının gücü olmuştur. Ayrıca Spotlight ekibinin bu başarısı araştırmacı gazeteciliğin toplumsal sorumluluğunun ne kadar önemli olduğunu da gözler önüne sermektedir.

Filmde Spotlight ekibinin editörü Walter Robinson ile ekibin muhabiri Sacha Pfeffier, Geoghan davası ile ilgili olarak Avukat Eric Mcleish'le görüştükleri sahnede Mcleish'in söylediği sözler özellikle mağdurların ve avukatlarının düştüğü suskunluk sarmalına işaret etmektedir:

R. Robinson: ...Kardinal Law'a karşı herhangi bir suçlama var mıydı?

E. Macleish: Evet, orası biraz karmaşık. Bir şeyi anlamanız gerek. Bunlar pis davalar. Zaman aşımı üç yıl ile sınırlı. Bu durumdaki mağdurların çoğu bu süreden daha önce öne çıkmıyor.

S. Pfeiffer: Neden peki?

E. Macleish: Daha çocuklar çünkü. Suçluluk, utanç... Ayrıca bu çocukların çoğu kötü mahallelerde büyüyor. Hiçbirisi böyle şeyleri duyurmak istemiyor. Hayatlarını değiştirmiş oluyorlar. Kendi yöntemleriyle mücadele etseler bile hayırsever dokunulmazlık yasası gereği sadece 20 bin dolar ceza kesiliyor.

S. Pfeiffer: Çocuk tacizine sadece 20 bin dolar mı?

E. Maclesih: Yasalara göre sistem böyle işliyor, evet. kilise güçlü bir oluşum. Yapılabilecek en etkili şey böyle davaları basın ile halletmek...

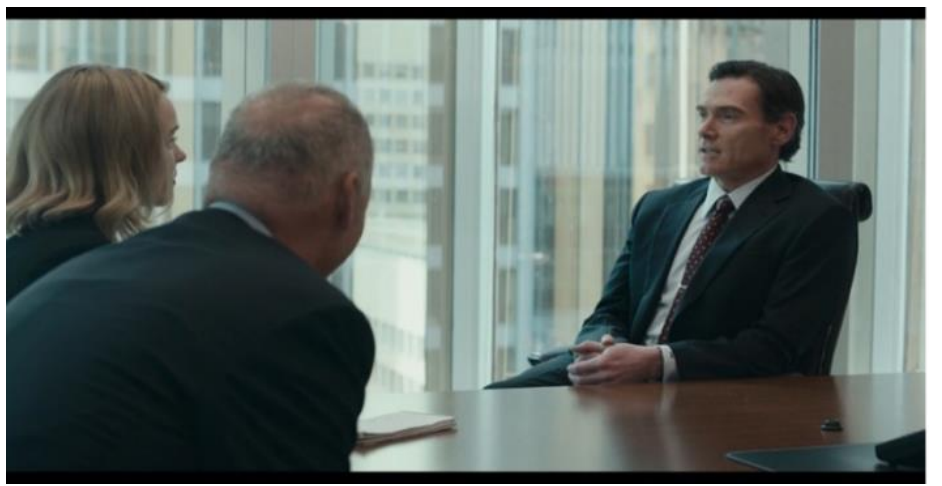

Görsel 2. Spotlight'in editörü W. Robinson ve muhabiri S. Pfieffer Avukat E. McLeish ile görüşmektedirler.

Spotlight ekibi muhabiri M. Rezendes'in mağdurların davalarına bakan M. Garabedian ile yaptığ ilk görüşme sahnesinde kilisenin bir avukatı susturmak için gösterdiği çabayı anlamaktayız:

M. Rezendes: ... Geçmişe dair bazı bilgiler almak istiyorum... 
M. Garabedian: Bunları kayıt altına almıyorsun değil mi?

M. Rezendes: Hayır, izninizi almadan yapmam.

M. Garabedian: Sana kilise belgelerini gösteremem. Niyetin buysa tabi. Mühürlüler.

M. Rezendes: Evet, biliyorum.

M. Garabedian: Massachusetts Barolar Birliği Kuruluna çă̆rllmadan önce üç kez önümü kestiklerini de biliyor musun? Beni çok yakından takip ediyorlar.

M. Rezendes: Kilise mi?

M. Garabedian: Evet, kilise.

M. Garabedian: Barodan atılmamı istiyorlar aslına bakarsan. Kaldır onu! Kaldir! (Not defteri)

M. Rezendes: Peki.

M. Garabedian: Bunlart herhangi bir şekilde kayıt altına almanı istemiyorum. Ne kâğıda ne de kasete. Seninle konuşmam bile yanlış...

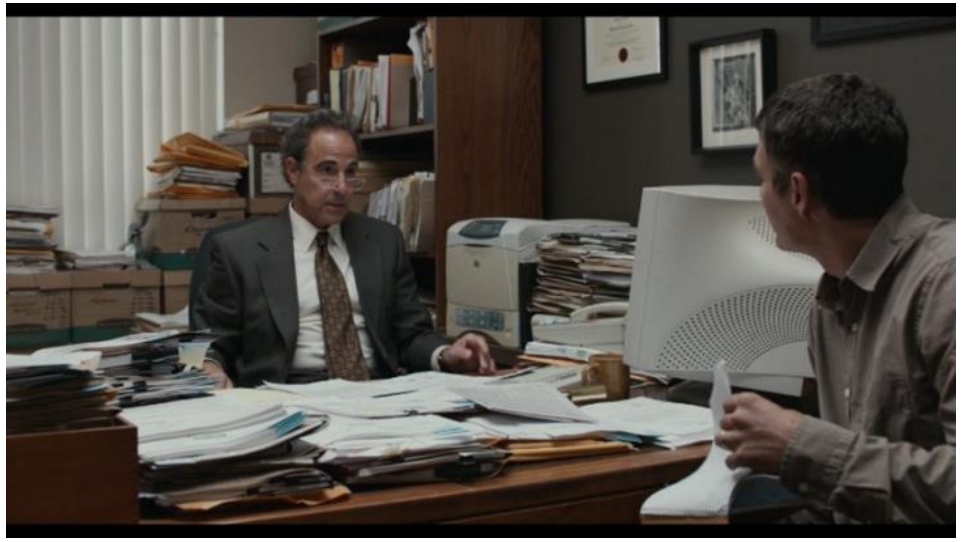

Görsel 3. Spotlight muhabiri M. Rezendes, Avukat M. Garabedian ile ofisinde görüşmektedir.

\subsection{Mağdur Kesim - Alt Tabakanın Çocukları}

Filmdeki bazı sahnelerde kilise rahiplerinin istismar ettikleri çocukların alt tabakadan ve yardıma muhtaç ailelerin çocukları olduklarını öğreniyoruz. Katolik inancının yaygın olduğu Boston'da özellikle alt tabakadan insanların kültüründe dine ve din adamlarına olan güvenin de bu durumda etkili olduğunu anlamaktayız. Filmde rahiplerin özellikle bu çocukları seçmelerinin nedeni ise yardım etme bahanesiyle bu çocuklarla kolayca temasa geçebilmeleri ve ailelerin böyle bir durumla karşılaştıklarında korku veya utançla durumu gizlemek isteyecekleri gerçeği olarak karşımıza çıkmaktadır.

Kilise rahiplerinin cinsel istismarına kurban olan çocukların hep aynı toplumsal gruplardan olmaları ve bu olayların uzun yıllar boyunca gizli tutulmuş olması, toplumun belli bir kesimine yönelik olarak sistemli bir suç işlendiğini göstermektedir. Filmde ifade edildiği rahipler, özellikle düşük gelirli ailelerin, anne ve babası boşanmış olanların çocuklarını ya da ebeveynleri olmayan çocukları yardım etme bahanesiyle seçmişlerdir. Bunun nedeni ise filmde, onların daha utangaç oldukları ve yaşadıkları olaylar hakkında konuşamayacak olmaları olarak ifade edilmektedir. $\mathrm{Bu}$ 
rahipler, alt sınıf içindeki çocukların ve ailelerinin kilise karşısında güçsüz olduklarını ve sesini çıkaramayacaklarını düşünerek suçlarını rahatça işleyebilmişlerdir. Seslerini duyurmak isteyenleri ise zaten kilise susturmaktadır. Böylece rahipler kendi din adamı kimliklerini kullanarak ve kilisenin itibarını ve gücünü suistimal ederek küçük çocukları istismar etme cesaretini kendilerinde bulmuşlardır.

Rahiplerin bu alt tabakadan çocuklara yönelik işlediği suçlar filmin birçok sahnesinde ifade edilmektedir. Walter Robinson ve Sacha Pfeiffer'in Avukat Eric Macleish ile görüştükleri ilk sahnede Macleish'in sözleri bu duruma açıklık getirmektedir ve bir önceki başlık altında sözler ifade edilmiştir. Aynı şekilde filmde Spotlight ekibinin ofisinde gerçekleşen görüşmede, rahiplerin istismarına uğrayan ve Rahip Tacizinden Kurtulanlar Derneğinin yöneticisi olan Phil Saviano'nun söylediği sözler de bu konuya açıklık getirmektedir:

P. Saviano: ...Fakir bir ailenin fakir bir çocuğuysanı din sizin için birçok şey demektir. Bir rahibin dikkatini çekerseniz ise bu önemli bir şeydir. İlahi kitabını getirmenizi istediğinde veya çöpleri çıkarmanızı istediğinde kendinizi özel hissedersiniz. Tipkı Tanrı'nın yardım istemesi gibidir...

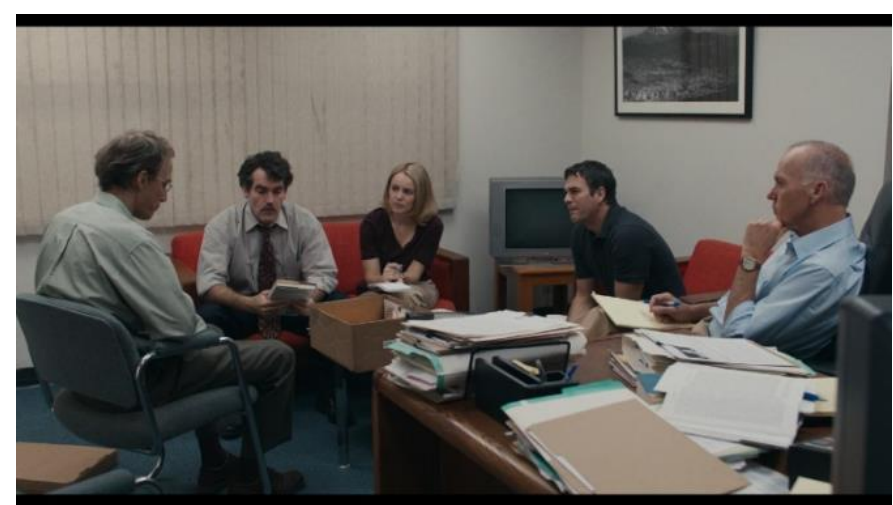

Görsel 4. Spotlight ekibi kendi ofisinde mağdur derneği yöneticisi olan P. Saviano ile görüşmektedir.

Filmde Avukat M. Garabedian'ın müvekkili olan mağdur Patrick ile Spotlight ekibi muhabiri M. Rezendes'in görüşmesinde Patrick'in söyledikleri de bu konu hakkında önemli detaylar barındırmaktadır:

M. Rezendes: ...Olay yaşandığında kaç yaşındaydınız?

Patrick: 12 yaşındaydım. Babam intihar ettikten hemen sonrasıydl.

M. Rezendes: İnanamiyorum.

Patrick: Pisliğin önde gideniydi. Annem de pek aklı başında biri değildi.

M. Rezendes: Nastl yani?

Patrick: Delinin tekiydi yani.

M. Garabedian: Şizofrendi...

M. Rezendes: Geoghan ile ne zaman tanışın?

Patrick: Kız kardeşim onu Dunkin' Donuts'ta görmüş. Babamın öldüğ̈̈nü söyleyince hemen yanımıza gelmişti... Geoghan çıkageldi. Annem birden havalara uçtu. Sanki Tanrı evimize gelmiş gibiydi... 


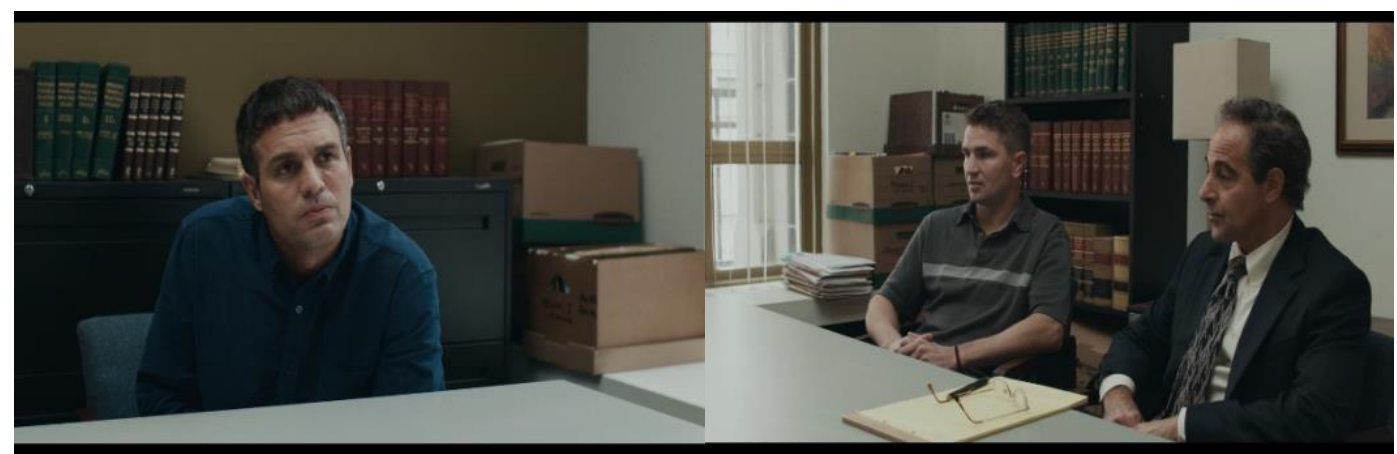

Görsel 5. Spotlight muhabiri M. Rezendes, Avukat M. Garabedian'ın ofisinde mağdurlardan Patrick ile görüşmektedir.

Bu sahnelerdeki ifadelerden anlaşılacağı üzere sapkın rahiplerin hedef aldığı çocuklar toplumun alt tabakasından olan ailelerin çocuklarıdır. Rahipler, din adamı kimliklerini kötüye kullanarak bu ailelerin çocuklarını tuzağa düşürmüşlerdir. Ancak asıl problem toplumun bu kesimine yönelik gerçekleştirilen suçlara karşı kilisenin, devlet kurumlarının ve genel olarak toplumun aldığı tutumdur. Kilise, rahiplerin suçlarını örtbas ederek ve mağdurları susmaya zorlayarak bu suça dahil olmaktadır. Suçlulardan şikayetçi olan mağdur ailelerine emniyetin veya yargı kurumlarının takındığı tavır da pek farklı değildir. Mağdurların avukatları susturulmakta, dava açıp mücadele edenler ise sadece 20 bin dolarlık tazminat elde edebilmektedir. Bir mağdur derneğinin yöneticisi olan Phil Saviano bu olayları basın yoluyla duyurmak istediğinde ise basın da konuya sırt çevirmiştir. Ancak sorumluluk sahibi araştırmacı gazetecilerin olayı takip etmeleri sonucunda üstü örtülen gerçekler ortaya çıkarılmıştır.

\subsection{Suçlu Rahipler ve Kilise}

Filmde Spotlight ekibinin araştırmasına konu olan cinsel istismar olayları, Boston'daki pedofili rahipler özelinden başlayarak genel olarak kiliselerde büyük boyutlara ulaşmış bir yozlaşmayı gözler önüne sermektedir. Kiliselerin itibar kaybetmemek için suçlu rahipleri korumaları ve işledikleri suçları gizlemeleri yozlaşmanın büyümesini sağlamış ve ortaya çıkan veriler büyük bir skandala dönüşmüştür. Filmin birçok sahnesinde rahiplerin bu davranışlarının sapkınlık derecesine vardığı ve bu sapkınlığın ülke genelinde yaygın bir fenomen haline geldiği ifade edilmektedir. Özellikle, uzun yıllar Kilise Tedavi Merkezlerinde çalışan ve pedofili rahipleri tedavi eden psikoterapist Richard Sipe'ın konuşmalarının geçtiği sahnelerde bu sapkınlığın boyutları ortaya çıkmaktadır. M. Rezendes'in psikoterapist R. Sipe ile ilk telefon konuşmasında geçen diyaloglar bu durumu ifade etmektedir:

R. Sipe: ...Kilise o adamların birkaç çürük elma olduğunu düşünmemizi istiyor Mike. Onlardan çok daha fazlası var.

M. Rezendes: Ne kadar fazla Richard?

R. Sipe: Araştırmalara göre konuşacak olursak yaygın bir psikolojik fenomen olduğunu söyleyebilirim...

Psikoterapist R. Sipe'ın Spotlight ekibi ile ekibin ofisinde gerçekleşen telefon konuşmasında söyledikleri konuyla ilgili detayları açığa kavuşturmaktadır:

R. Sipe: ...Krizi tam anlamiyla anlamak istiyorsanı dini sebeplerden ötürü cinsellikten uzak durma gereğiyle başlamalısınız. Bu benim ilk büyük bulgumdu. Rahip sinıfinın sadece yüzde 50'si cinsellikten uzak duruyor. Çoğunluğu diğer yetişkinlerle cinsel ilişki yaşlyor. Ama bu durumdan, pedofiliye müsamaha gösteren hatta onu koruyan bir gizlilik olgusu 
meydana geliyor.

S. Pfieffer: Yani kilisenin bu krizin boyutundan haberi var diyorsunuz?

R. Sipe: Kesinlikle...

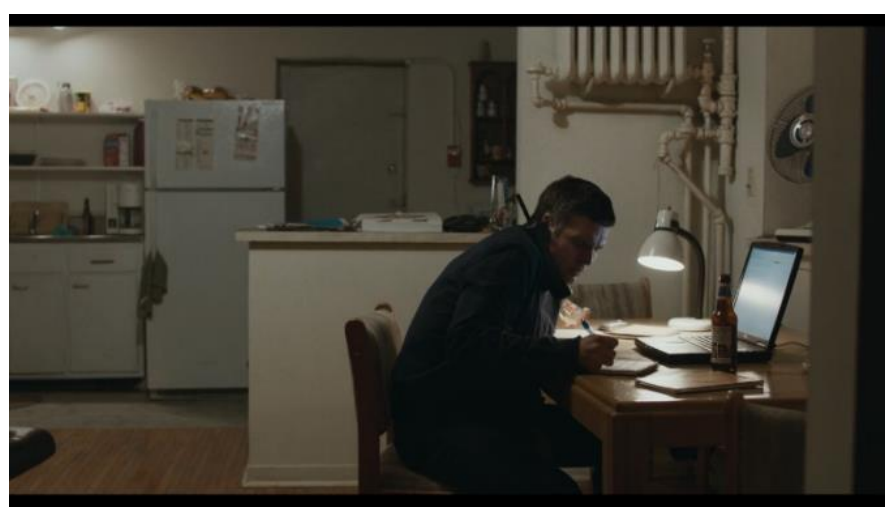

Resim 6. Spotlight muhabiri M. Rezendes telefonda psikoterapist R. Sipe ile görüşmektedir.

M. Rezendes ile R. Sipe arasında geçen telefon konuşmalarında Sipe, rahipler arasında oluşan bu sapkınlık durumunu Katolik inancının geleneklerinden gelen, din adamlarının evlenmeme ve dolayısıyla cinsel yaşamdan uzak durma eylemine dayandırmaktadır. Sipe'a göre bu rahiplerin psikoseksüel gelişimleri engellenmiştir ve bunun neticesinde rahiplerin sosyal yaşamlarında ortaya çıkan problemler onları başka yollara itmektedir. M. Rezendes ile R. Sipe arasında geçen bir telefon konuşmasında bu duruma değinilmektedir:

R. Sipe: Tedavi ettiğim çoğu rahibin psikoseksüel olarak büyümesi engellenmişti. Duygusal seviye olarak 12 ya da 13 yaşındaydılar.

Kilise rahiplerinin bu durumu yaygın bir fenomen olarak gözükse de burada asıl problem bu durumdan haberdar olan kilise yönetiminin ortaya çıkan sorunları göz ardı etmesi ve kilise hakkında çıkan iddiaları kimsenin dikkate almamasıdır. Kilisenin gücü dolayısıyla diğer devlet kurumlarıyla ilişkisi de ortadayken kimse bu konunun üzerine gitmek istememiştir. Bu noktada ise olaylara dışarıdan bakan bir göz olarak Marty Baron’un dikkat çekmesi önemli görülmektedir. Marty Baron bir gazeteci olarak sorumluluğunu yerine getirmiş ve hiç kimsenin yapamadığı ya da yapmayı düşünmediği bir şekilde toplumun en önemli kurumlarından birini sorgulamış ve takip etmiştir.

\section{SONUÇ}

$\mathrm{Bu}$ çalışmada; toplumsal anlamda araştırmacı gazeteciliğe yüklenen misyona uygun bir şekilde, Spotlight filminde araştırmacı gazeteci ekibinin sorumluluk üstlenerek gerçeği ortaya çıkarma gayreti içinde olduğu ve bütün risklere karşın kamu yararı gözeterek mesleki gerekliliğini yerine getirdiği gözlenmiştir. Toplumun içine girdiği suskunluk sarmalı sürecinde üstüne düşen görevi yapan Spotlight ekibi kilisenin baskısına göğüs germiş ve kurumları hesap vermeye zorlayarak kamunun vicdanı olmuştur. Bütün bu veriler ışığında filmde, araştırmacı gazetecilik deneyiminin toplumsal bir rolünün olduğu ve mesleki sorumluluğu gereği gerçeği görünür k1lma gayreti içinde olduğu sonucuna varılmıştır. Filmde araştırmacı gazetecilik mesleği üzerine çizilen bu çerçeve meşrulaştırılmakta ve gazeteciler toplumun bekçileri olarak resmedilmektedir. Aynı zamanda muhabirlere ve araştırma süreçlerine dair önemli izlenimler sunmaktadır. 


\section{KAYNAKÇA}

Akçalı., S. (1998). Türkiye'de araştırmacı gazetecilik ve sorunları. (Yayımlanmamış Doktora Tezi). Ege Üniversitesi Sosyal Bilimler Enstitüsü.

Arık., E. \& Akgün., H. (2019). Türk sinemasında gazeteci kimliğinin temsili. Türkiye Illetişim Araştırmaları Dergisi. 34, 196-220.

Armağan., A. (2012). Bir uzmanlık alanı olarak araştırmacı gazetecilik. İstanbul Üniversitesi İletişim Fakültesi Dergisi, 0 (7), 77-88.

Aucoin., J, L. (2005). The evolution of American investigative journalism. University of Missouri Press.

Brooks., B, S. \& Kennedy., G. \& Moen., D. R. \& Ranly., D. (1985). News reporting and writing. St. Martin's Press.

Diken., B. \& Laustsen., C, B. (2011). Filmlerle sosyoloji. Metis Yayınları.

Ehrlich., M, C. (2004). Journalism in the movies. University Of Illinois Press.

Ekhareafo., D. \& O., Okoro, \& F., E, Olley, W. O. (2016). Investigative and interpretative journalism: an insight into critical and review writing. Trust Publications.

Ettema., J. \& S., Glasser, T, L. (1988). Narrative form and moral force: the realization of innocence and guilt through investigative journalism. Journal of Communication, 38(3), 8-26.

Güçhan., G. (1993). Sinema-toplum ilişkileri. Kurgu Dergisi (12), 51-71.

Hunter., M, L, \& Hanson., N. (2011). What is investigative journalism? M. L. Hunter içinde, storybased inquiry: A Manual for Investigative Journalists. 7-12. UNESCO Pulishing.

İrvan., S. (2018). Araştırmacı gazetecilik: kavramsal bir değerlendirme. Üsküdar Üniversitesi İletişim Fakültesi Akademik Dergisi (2), 70-94.

Kabadayı., L. (2018). Film eleştirisi: kuramsal çerçeve ve sinemamızdan örnek çözümlemeler. Ayrıntı Yayınları.

McNair., B. (2011). Journalism at the movies. Journalism Practice, 5(3), 366-375.

Öncel., G, K. (2012). Soruşturmac1 gazeteciliğin demokrasilerdeki yeri: kuramlar ve uygulamalar. (Yayımlanmamış Doktora Tezi). Marmara Üniversitesi Sosyal Bilimler Enstitüsü.

Özden., Z. (2004). Film eleştirisi. İmge Kitabevi.

Protess., D, L. \& Cook., F, L. \& Doppelt., J, C. \& Ettema., J, S. \& Gordon., M, T. \& Leff., D, R. \& Miller., P. (1991). The journalism of outrage: investigative reporting and agenda building in America, The Guilford Press.

Rezendes., M. (2002, Ocak 06). Church Allowed Abuse By Priest For Years. bostonglobe.com: https://www.bostonglobe.com/news/special-reports/2002/01/06/church-allowed-abuse-priest-foryears/cSHfGkTIrAT25qKGvBuDNM/story.html adresinden alındı

Tokgöz., O. (2013). Temel gazetecilik. İmge Kitabevi.

Uzun., R. (2006). Gazetecilikte yeni bir yönelim: yurttaş gazeteciliği. Selçuk Üniversitesi Sosyal Bilimler Enstitüsü Dergisi (16), 633-656.

Williams., P, N. (1978). Investigative reporting and editing. Prentice-Hall. 